\title{
Pleistocene Deer Fauna in Crete: Its Adaptive Radiation and Extinction
}

\author{
John de Vos National Museum of Natural History, P.O. Box 9517, 2300 RA Leiden, The Netherlands
}

\begin{abstract}
Besides mass extinction, adaptive radiation is a common phenomenon, it can be found in all taxa. The scale of adaptive radiation depends on time and plasticity of the organism. The presence of several morphotypes or species of Pleistocene cervids on Crete is explained by De Vos (1996) as an adaptive radiation, in a one-invasion, one-radiation model. The Cretan deer became extinct at the arrival of man, about $8000 \mathrm{BP}$.
\end{abstract}

Key words: Crete / island fauna / unbalanced / endemic / adaptive radiation / extinction / taxonomy

The history of life on earth is characterized by biodiversity. Since Darwin (1859) there has been a general agreement that a new species originates from another species by evolution.

Also since Darwin there is a general agreement that the mechanism behind the evolution is 'natural selection'. Darwin (1859: 81) himself wrote: "This preservation of favourable variations and the rejection of injurious variations, I call "Natural Selection". On page 469 Darwin (1859) wrote concerning the selection of the modifications: "What limit can be put to this power, acting during long ages and rigidly scrutinizing the whole constitution, structure, and habits of each creature, - favouring the good and rejecting the bad? I can see no limit to this power, in slowly and beautifully adapting each form to the most complex relations of life".

When a taxon is adapted, and the characters are successful and there are available 'empty' niches, an adaptive radiation of that taxon will follow. Darwin wrote (page 303): "I may recall a remark formerly made, namely that it might require a long succession of ages to adapt an organism to some new and peculiar line of life, for instance to fly through the air; but that when this had been effected, and a few species had thus acquired a great advantage over other organisms, a comparatively short time would be necessary to produce many divergent forms, which would be able to spread rapidly and widely throughout the world". So, in the view of Darwin, adaptation is slow, while radiation is fast. However, the punctuationalist debate (Gould \& Eldridge, 1977) opened the possibility that gradual change driven by Darwinian selection and population dynamics is not the only mode of evolutionary transformation. Speciations appear as relatively rapid events separated by long periods of relative stasis.

Adaptive radiation is a common phenomenon. The degree of adaptive radiation depends on time and plasticity of the organism. Large-scale, long-term radiations are the most conspicuous of all 
macro-evolutionary phenomena (Carroll, 1997) and in this adaptive radiation is strong. We find this in all taxa. Good examples of these are: the adaptive radiation of the placental mammals and birds during the Cainozoic. Adaptive radiation we find on the continents as well as on continental islands. Examples of continental islands are South America and Australia. In so-called small-scale, short-term evolution, adaptive radiation will be weaker. The most famous examples of this are the type of adaptive radiation we find on islands with an oceanic origin, like the Galapagos Islands.

The islands of the Galapagos were very important for Charles Darwin's ideas concerning evolution. It was here that Darwin discovered that, although the animals show signs of a resemblance with the ones of Patagonia, they are different from them. Secondly he realized that species differ from island to island, even if the islands are separated less than $100 \mathrm{~km}$ from each other. His attention to that was attracted by the birds and the statement of Mr Lawson, an Englishmen, who was vice governor of the Archipelago, that he could tell immediately from which island a particular tortoise came. The study of Lack (1947) showed that, although the size, plumage and bodies of the birds of the Galapagos Islands were superficially seen similar in appearance, the differences in beaks indicates an adaptation to different habitats. It became clear that islands had species, which were different from the mainland and were adapted to the different habitats of islands.

Islands are sometimes called the laboratories of evolution. In so-called oceanic islands, which could only be reached by a few species which can swim (like elephants, hippos and deer), float or fly to the islands, the species will adapt to the different habitats of that island and adaptive radiation will take place. Such cases are well known for recent island communities, but they are underestimated for fossil communities. The purpose of this paper is to show that the fossil Cretan cervids are an example of such a fossil community in which adaptive radiation took place.

\section{CERVIDS OF CRETE}

\section{The Pleistocene fauna of Crete}

From the literature (Bate 1905, 1907; Simonelli 1907, 1908; Kuss 1965, 1966, 1973, 1975a \& b; De Vos 1979, 1984; Capasso Barbato \& Petronio 1986; Capasso Barbato 1989, 1990, 1992a \& b; Boekschoten \& Sondaar 1966; Kuss \& Misonne 1968; Mayhew 1977; Reumer 1986; Reumer \& Payne, 1986; Symeonidis \& Sondaar 1971; Weesie 1982, 1987; Willemsen, 1980; Bachmayer et al., 1975) it is clear that the fauna of Crete only contains cervids, hippos, murids, shrews, elephants, birds and reptiles, while large carnivores, with the exception of the otter, are lacking. A fauna with a restricted group of mammal species (mostly endemic) is designated as an unbalanced fauna (Sondaar 1971, 1977). The mammals found in Crete were endemic, which means that they were restricted to Crete it-self. The endemic unbalanced fauna points to isolation of Crete during the Pleistocene (Sondaar 1971, 1977). According to Sondaar \& Boekschoten (1967) and Dermitzakis \& Sondaar (1978) the mammals, including the cervids, reached the island by swimming or drifting. When they arrived on the islands there were a lot of habitats and empty niches.

\section{The number of species and their adaptations}

In a biometrical approach of post cranial and cranial material from several sites, De Vos (1979) distinguished six size groups in the fossil remains of the Pleistocene deer from Crete. In one of the 
size-groups he distinguished three morphotypes of skulls and antlers, leading to eight taxonomic units. Capasso Barbato (1989, 1990, 1992b), Capasso Barbato \& Petronio (1986), Petronio (1990) and Caloi \& Palombo (1996) consider five species to be present. In this paper the opinion of De Vos (1984) is followed that there are 8 taxonomic units attributed to one genus: Candiacervus.

\section{Size 1) Candiacervus ropalophorus De Vos, 1984}

This is the smallest deer found so far in Crete. It had a withers height of about $40 \mathrm{~cm}$. Characteristic of this species is that it has relative shortened metacarpal and the limb-bones are relatively more massive than in Cervus elaphus. Some metatarsals (6\%) are fused with the naviculo-cuboid; $68 \%$ of the naviculo-cuboids are fused with the central cuneiform (De Vos, 1979). The shortening of the metapodials and the frequent fusion of the metatarsus with the navico-cuboid are interpreted by Leinders \& Sondaar (1974) as an adaptation of the locomotory system to island environments. Speed and zigzag movements lost their significance of the absence of carnivores. Through the shortening of the legs the centre of gravity was lowered, resulting in a greater stability. Through the fusion of the tarsals the foot became less vulnerable. This low-gear locomotion was advantageous in the mountainous environments lacking carnivores (Leinders, 1979).

The $\mathrm{P}^{2}$ is characterized by a protocone that is similar in size to the hypocone.

The antlers are very peculiar; they are long (up to $77 \mathrm{~cm}$ ) for such small animals. The antler has only a brow-tine, which is placed about $10 \mathrm{~cm}$ from the burr; this is called sub-basilar. The occlusal surfaces of the tooth rows in middle-aged animals are flat and the teeth are rather hypsodont.

\section{Size 2) Candiacervus spp. II}

In size following Candiacervus ropalophorus are three species with the same size (withers height about $50 \mathrm{~cm}$ ), but different in skull morphology and antlers. These three species are indicated as Candiacervus sp. IIa, IIb and IIc. They also had shortened and more massive legs. This shortening is of the same degree as in Candiacervus ropalophorus. Also here the occlusal surface of the teeth is flat and the teeth are rather hypsodont, which suggests that they have eaten more grasses.

These short-legged, small, heavily built characters cannot be considered as being due to ontogenetic scaling or paedomorphic changes. The relative shortening of the legs is not directly connected with dwarfism, but must have a special adaptational meaning (Sondaar, 1977). Sondaar (1977) pointed out that shortening of the leg reduces locomotion speed. The faunas, to which the dwarfish and short legged forms belong, are so-called unbalanced faunas (Sondaar, 1977). These faunas lack carnivores. For these short-legged species there was no need to be able to move at high speed, since there were no predators to escape from. On the other hand, short distal parts of the legs might be advantageous in foraging in the mountainous environment of islands (Sondaar, 1977).

In her unpublished thesis Capasso Barbato (1989) attributed without giving arguments the material of size 2 to the species Candiacervus ropalophorus De Vos, 1984 (= size 1). They called it Megaceros (Candiacervus) ropalophorus, although De Vos (1979) clearly proved statistically that the populations of the site Gerani 4 (with Candiacervus ropalophorus) and Liko (with Candiacervus II taxonomical units) are significant by different in size. These two sizes are called Megaceros 
(Candiacervus) ropalophorus by Capasso Barbato, 1989 and Megaceroides (Candiacervus) "ropalophorus" by Caloi \& Palombo (1996). Further Capasso Barbato (1989) ignored the distinction in antler morphology in species IIa, b, c, without discussing it. Caloi \& Palombo (1996) stated concerning this that in the endemic cervids the variability in antler morphology is usually wide and refer to Megaceroides cazioti of Dragonara cave in Sardinia (Caloi \& Malatesta, 1974). Further, Caloi \& Palombo (1996) stated that among the forms referred by Capasso Barbato to M. ropalophorus, the analysis of the characters connected with the chewing functions shows that in the skulls and jaws it is possible to recognize two extreme morphotypes, independent of sexual dimorphism (at least concerning the skull) and of the size.

Size 3) Candiacervus cretensis (Simonelli, 1907) (=Megaceros (Candiacervus) cretensis of Capasso Barbato, 1989; =Megaceroides (Candiacervus) cretensis of Caloi \& Palombo, 1996).

According to Caloi \& Palombo (1996) characteristics of a grazer prevail in the jaw of this species. This species had a withers height of about $65 \mathrm{~cm}$. The legs were also shortened, but to a lesser degree than the previous species. Caloi \& Palombo (1996) attributed, based on the scarce information available, to Candiacervus cretensis a certain aptitude to moving on relatively hard ground, with no great agility, and little or no jumping ability.

Size 4) Candiacervus rethymnensis Kuss, 1975 (=Cervus (Leptocervus) rethymnensis of Caloi \& Palombo, 1996; = ?Pseudodama rethymnensis of Caloi \& Palombo, 1996.

This is a species which as to length of its legs, is comparable to the mainland species Cervus elaphus. It had a withers height of about $90 \mathrm{~cm}$. This species and the following two species are only known from their post-cranial skeletal elements.

Size 5) Candiacervus sp. V (= "Cervo taglia media" of Kotsakis et al., 1976; = Cervus (Leptocervus) dorothensis of Capasso Barbato, 1989, see also Capasso Barbato 1990, 1992 a and b; = ?Pseudodama (Leptocervus) dorothensis of Caloi \& Palombo, 1996).

Size 6) Candiacervus sp. VI (= "Cervo taglia grande" of Kotsakis et al., 1976; = Cervus major Capasso Barbato \& Petronio, 1986; Cervus (Leptocervus) major of Capasso Barbato, 1989; = ?Pseudodama (Leptocervus) major of Caloi \& Palombo (1996).

In these two species the occlusal surfaces of the teeth are lophodont, which suggests that they may have eaten more branches and leaf-like food. Both species are characterized by the fact that their leg bones are more slender than any species on the continent. Candiacervus $\mathrm{sp}$. V possessed a withers height of about $120 \mathrm{~cm}$. According to Caloi \& Palombo (1996) this species had a rather slow and stiff locomotion.

Candiacervus sp. VI had a withers height of about $165 \mathrm{~cm}$. According to Caloi \& Palombo (1996), based on the scarce information available, the flexion possibilities of the autopodium were extremely limited and deambulation rigid and slow.

Although there are different opinions concerning the number of cervid species in Crete, it is clear that we can observe a change in the locomotion system and the chewing apparatus.

ANCESTORS 
In the past different hypotheses have been postulated concerning the relation of the fossil Cretan deer with main-land species. It has been suggested (Azzaroli 1953a, 1961, 1977; Kuss 1965, 1966, 1967; Kuss \& Misonne 1968; Kurtén 1968; Sondaar 1971; Accordi 1972; Malatesta 1980; Capasso Barbato, 1989, 1990, 1992a and b; Caloi \& Calombo, 1996) that there is a relationship between the various dwarfed deer of the Mediterranean islands, including Crete, as a group and the large continental cervids of the Pleistocene: Eucladoceros of the Villafranchian, Praemegaceros of the Middle Pleistocene and Megaceros of the Upper Pleistocene.

Kuss (1975b) rejected a relationship of the Cretan deer with the megacerines. He created a new genus, Candiacervus, with two species in Crete, a small one (Candiacervus cretensis) and a large one (Candiacervus rethymnensis).

Sickenberg (1975) described a deer Cervus peloponnesiacus from the Megalopolis Basin (Peloponnensis, Greece), and believed that it was the ancestor of the Cretan deer for the following reasons:

1) the great resemblance in morphology of the antlers;

2) the tendency towards hypsodonty in the teeth;

3) the variability in the size of the extremities;

4) the paleogeographical and paleoecological situation.

At variance with this hypothesis are the facts that the antlers of Cervus peloponnesiacus are too fragmentary for an exhaustive comparison, and the brow-tine is placed too low. Furthermore, the variability in size of the extremities is absent in the Cretan deer as is indicated in the study of De Vos (1979). There is too little teeth material for measuring hypsodonty in Cervus peloponnesiacus, and finally paleogeography and paleoecology are not very strong arguments for phylogeny.

Capasso Barbato \& Petronio (1986) attributed the large species to the genus Cervus again, based only on the resemblance of postcranial elements, with Cervus peloponnesiacus and Cervus philisi. The difference they (Capasso Barbato \& Petronio, 1986) speak of is the fact that the metapodials are much more slender than any continental form. However, this is no good argument, as the taxonomy of cervids is based on antlers, and sometimes cervids with identical postcranial elements in size and morphology, but with different antlers, are put in different genera (like Cervus perrieri and Arvernoceros ardei; Heintz, 1970). In 1989 Capasso Barbato created a new subgenus (Leptocervus) for the large species.

Capasso Barbato (1992b) follows the opinion that the ancestor of the larger Cretan species might be Cervus peloponnesiacus found at Megalopolis (Peloponnesus) (Sickenberg, 1975). The large cervids would be derived from cervid populations with thin limb bones of lower Middle Pleistocene times.

Capasso Barbato (1989, 1990, 1992a and b) considered the smaller species to be Megacerini of the "verticornis" group (sensu Azzaroli) and put them in the subgenus Candiacervus of the genus Megaloceros (in the paper of 1989 and 1990 indicated as Megaceros).

Caloi \& Palombo (1996) put sizes 1, 2, 3 in the continental genus Megaceroides, while the sizes 4, 5 and 6 are put in the continental genus ?Pseudodama, without giving arguments.

I still hold the opinion that the data now available are insufficient to conclude firm phylogenetic relationship between the mainland forms and the Cretan cervids. Adopting the genus name 
Candiacervus for all the Cretan species is still the best solution.

Concluding we may say that there is no known relative of the Cretan deer on the mainland, although various candidates have been suggested as ancestor.

\section{SPECIATION}

In the past different hypotheses concerning speciation have been postulated. De Vos (1984, 1987, $1988)$ and De Vos \& Dermitzakis $(1985,1986)$ and Dermitzakis \& De Vos $(1985 / 86,1987)$ discussed these hypotheses and added a few more. They speculated on the possible mode of development of the different taxa of the Cretan deer. They discussed five models

\section{-1. One invasion-Single lineage model}

De Vos (1984) and De Vos \& Dermitzakis (1985, 1986), Dermitzakis \& De Vos $(1985 / 86,1987)$ and De Vos $(1987,1988)$ rejected this model, because it implies that one has to find the largest forms in the older deposits and the smallest in the younger sites. Furthermore, one cannot find more than one taxon per horizon per site. These conditions are contradicted by the fact that the largest form has been found in localities of relatively young age and different taxa were frequently found in the same horizon.

\section{-2. Two Invasion-Two lineages model}

This model does not explain the presence of three or more species in the same horizon.

\section{-3. More invasions model}

The most extreme number of invasions could be six, based on the size groups. This model was rejected for paleontological and morphological reasons.

\section{-4. One Invasion-Radiation Model}

In this model, it is supposed that the cervids originated from one ancestral stock, in which some kind of radiation took place. This is based on the fact that in several stratigraphic horizons several taxa were found, so that one has to accept that the different taxa actually lived at the same time.

\section{-5. Two Invasions-Two radiations model}

In this model, it is supposed that the cervids originated from two ancestral stocks, in which some kind of radiation took place.

De Vos (1979) published a table with the biostratigraphy for the Pleistocene of Crete. Based on the data given in that table he suggested that there were two invasions of cervids. Capasso Barbato (1992b) and Caloi \& Palombo (1996) followed this idea. Recently De Vos (1996), based on literature study and his own observations, concluded that there was only one invasion. He suggested in Crete a faunal turnover, in which a fauna with pygmy elephant and pygmy hippo and large murids was succeeded with a fauna with cervids, a large elephant and a small murid. So, model 5 is not realistic, so what is left is the one-invasion, one-radiation model, model 4.

In which way the speciation took place is not clear. The locomotion mechanism must be punctuated. In other parts of the cervids gradual genetic changes may have played a role. Although we can not exclude allopatric speciation, it is more realistic to suppose that the speciation took place in Crete itself. So what is left are parapatric speciation and sympatric speciation. As there are no great differences in habitat, parapatric speciation seems not very likely, but cannot be excluded either. Sympatric speciation is the likeliest, but cannot be proven yet.

\section{EXTINCTION}


After the faunal turnover within the genus Candiacervus an extreme radiation took place, reflected in at least eight species. Both in Simonelli cave (Suriano in Malatesta, 1980) as well as in Liko (Weesie, 1987), cold-loving birds are found. Possibly these sites represent cold periods and because in Simonelli the elephant is present, while it is absent in Liko, they represent probably two different cold periods. After the cold period of Liko the climate became warmer and the island smaller by sea level rising. The change in habitat possibly caused the extinction of the deer taxa, with the exception of Candiacervus ropalophorus, which is still found as the only species in the localities Gerani 23 (main layer, Gerani 5 and 6).

Man and the introduced domestic animals probably caused the extinction of Candiacervus ropalophorus. This we can deduce from the finds of Gerani 2: Above the main layer $\mathrm{Ge} 23$ in which we find only Candiacervus ropalophorus, there is a layer without this species, but with traces of human activities. In this layer Mus minotaurus is still present. There is no clear sedimentary break between this layer and the layer Ge23. The extinction of Candiacervus must have taken place in the Holocene, with the arrival of Man, about $8000 \mathrm{BP}$. The somewhat later extinction of Mus minotaurus probably was caused by competition of Rattus and recent Mus, which accompany every human invasion.

\section{DISCUSSION AND CONCLUSIONS}

Although there are different opinions concerning the number of cervid species in Crete, it is clear that the species differ in dental, cranial and postcranial morphology, which point to the fact that they must be adapted to different habitats and occupy different niches. There was only one invasion and the species originated from an still unknown ancestor from the continent. The speciation of the Cretan cervids is clearly a case of adaptive radiation as was suggested already by De Vos (1996).

\section{REFERENCES}

Accordi, B., 1972. Lo scavo della "Grotto Simonelli", con cervi nani del Quaternario, effettuato a Creta nel 1971 dall'Istituto di Geologia e Paleontologia dell'Università di Roma, con il finanziamento dell'Accademia Nazionale dei Lincei. Quaderno Accademia Nazionale dei Lincei 167: 1-17, Roma.

Azzaroli, A., 1953. La sistematica dei cervi gigantei e i cervi nani delle isole. Atti della Societa Toscana di Scienze Naturali, Memorie, A, 59 (1952): 119-127.

- 1961. Il nanismo dei cervi insulari. Palaeontographia Italalica, Vol. LVI, Paleontologia ed ecologia del Quaternario, vol IV, Memoria nr. 1 Pisa: 1-32.

, 1977. Considerazioni sul mammiferi fossili delle isole Mediterranee. Bollettino di Zoologia 44: 201-211, Padova.

Bachmayer, F., Brinkerink, J. P. \& Symeonides, N., 1975. Pleistozäne Schildkröten aus Höhlen der Insel Kreta. Annales Géologiques des Pays Helléniques 27: 110-122, Athena.

Bate, D. M. A., 1905. Four and a half Months in Crete in search of Pleistocene Mammalian Remains. 
Geological Magazine, n.s., Dec., V, vol. II, no. V: 193-202, London.

, 1907. On Elephant Remains from Crete, with Description of Elephas creticus n. sp. Proceedings of the Zoological Society of London, pp. 238-250.

Boekschoten, G. J. \& Sondaar, P. Y., 1966. The Pleistocene of the Katharo Basin (Crete) and its Hippopotamus. Bijdragen tot de Dierkunde, Aflevering 36 (8): 17-44.

Caloi, L. \& Palombo, M. R., 1996. Functional aspects and ecological implications in Hippopotami and cervids of Crete. In: Reese, D. S., ed., Pleistocene and Holocene Fauna of Crete and its First Settlers. Monographs in world Archeology 28:125-151.

— \& Malatesta, A., 1974. Il cervo pleistocenico di Sardenna. Memorie dell'Istituto Italiano di Paleontologia Umana Firene? Roma 2: 163 -247.

Capasso Barbato, L., 1989. Cervidi endemici del pleistocene di Creta. Dottorato in Palaeontologia, Modena-Bologna, Vol. I and II.

, 1990. Les Cervidés endémiques de Crètes. Quaternaire 3-4:265-270.

- 1992a. Nuova specie di cervide del pleistocene di Creta. Atti della accademia Nazionale dei Lincei, Memorie Lincee, Scienze Fisische e Naturali, serie IX, Vol. 1, Fascicolo 7: 183-220.

- 1992b. Observations on the biostratigraphy of Cretan Pleistocene vertebrates. Il Quaternario 5 (1): 67-76.

— \& Petronio, C., 1986. Cervus major n. sp. of Bate Cave (Rethymnon, Crete). Atti della Accademia Nazionale dei Lincei, Memorie, classe di Scienze fisischi, matematische e naturali, Serie VIII, vol. XVIII, Sez. IIa (Fisica, chimica, geologia, paleontologia e mineralogia), fascicolo 2: 59-100. Roma.

Carroll, R. L., 1997. Patterns and Processes of Vertebrate Evolution, 448 pp. Cambridge University Press.

Darwin, C., 1859. On the Origin of Species by Means of Natural Selection, or the Preservation of Favoured Races in the Struggle for Life, $490 \mathrm{pp}$. Murray, London.

Dermitzakis, M. D. \& Sondaar, P. Y., 1978. The importance of fossil mammals in reconstruction paleogeography with special reference to the Pleistocene Aegean Archipelago. Annales Géologiques des Pays Helléniques 46: 808-840, Athena.

— \& De Vos, J., 1985-86. Mammal faunal succession and evolution during the Pleistocene in Cretan Paleoenvironment. Annales Geologiques des Pays Helleniques, series 1, 33 (1): 101-137. (in Greek).

— \& De Vos, J., 1987. Faunal succession and the evolution of Mammals in Crete during the Pleistocene. N. Jb. Geol. Palaont. Abh. 173 (3): 377-408.

De Vos, J., 1979. The endemic Pleistocene deer of Crete. Proceedings of the Koninklijke Nederlandse Akademie van Wetenschappen, Amsterdam, Series B, 82 (1): 59-90.

$\longrightarrow$, 1984. The endemic Pleistocene deer of Crete. Verhandeling der Koninklijke Nederlandse Akademie van Wetenschappen, Afdeling Natuurkunde, Eerste reeks, Deel 31. 100 pp. NorthHolland Publishing Company, Amsterdam, Oxford, New York.

- 1988. The radiation of the endemic Pleistocene deer of Crete. Abstracts of the International Conference "Early Man in Island Environments", Oliena (Sardegna), 25 Settembre-2 Ottobre, 1988: 10-11.

_ 1996. Taxonomy, Ancestry and Speciation of the Endemic Pleistocene Deer of Crete 
Compared with the Taxonomy, Ancestry and Speciation of Darwin's Finches. In: Reese, D. S., ed., Pleistocene and Holocene Fauna of Crete and its First Settlers. Monographs in World Archeology 28: 111-124.

— \& Dermitzakis., M. D., 1986. Models of the development of Pleistocene deer on Crete (Greece). Modern Geology 10: 243-248.

$-\&-, 1985$. Model proposals on the development of the Pleistocene deer of Crete. Abstracts E. U. G. Strassbourg 1-4 April 1985, Terra Cognita 5: 2-3.

Gould, S. J. \& Eldridge, N., 1977. Punctuated equilibria: The tempo and mode of evolution reconsidered. Paleobiology 3: 115-51.

Heintz, E., 1970. Les Cervidés Villafranchiens de France et d'Espagne, Volume I et II. Mémoires du Muséum National D'Histoire Naturelle Nouvelle Série, Série C, Sciences de la Terre, Tome XXII, Fascicule Unique, Paris.

Kurtén, B., 1968. Pleistocene mammals of Europe, 317 pp. Weidenfeld and Nicholson, London.

Kuss, S. E., 1965. Eine pleistozäne Säugetierfauna der Insel Kreta. Berichte der Naturforschenden Gesellschaft zu Freiburg im Breisgau 55 (2): 271-348.

- 1966. Beitrage zur pleistozänen-Fauna der Insel Kreta. I. Die von Bate 1904 gesammelten Elefanten und Cervid en Reste. Berichte der Naturforschenden Gesellschaft zu Freiburg im Breisgau 56 (2): 169-181.

$\longrightarrow$, 1967. Pleistozäne Säugetierfunde auf dem ostmedi-terranen Inseln Kythera und Karpathos. Berichte der Naturforschenden Gesellschaft zu Freiburg im Breisgau 57 (2): 207-216.

- 1973. Die pleistozänen Säugetierfaunen der ostme-diterranen Inseln. Berichte der Naturforschenden Gesellschaft zu Freiburg im Breisgau 93 (1-2): 49-71.

$\longrightarrow$, 1975a. Hippopotamus creutzburgi parvus n. spp., ein pleistozänes Zwergflusspferd von der Insel Kreta. Berichte der Naturforschenden Gesellschaft zu Freiburg im Breisgau 65 (1-2): 5-23.

— 1975b. Die pleistozänen Hirsche der ostmediterranen Inseln Kreta, Kasos, Karpatos und Rhodos (Griechenland). Berichte der Naturforschenden Gesellschaft zu Freiburg im Breisgau 65 (1-2): 25-79.

— \& Misonne, X., 1968. Pleistozäne Muriden der Insel Kreta. Neues Jahrbuch für Mineralogie, Geologie und Paläontologie. Abhandlung. 132 (1): 55-69.

Lack, D., 1947. Darwin's Finches, 208 pp. Cambridge University Press, Cambridge.

Leinders, J. J. M., 1979. On osteology and function of digits of some ruminats and their bearing on taxonomy. Zeitschrift für Säugetierkunde 44 (5): 305 -318.

Leonders, J. J. M. \&. Sondaar, P. Y., 1974. On functional fusion in footbones of Ungulates. Zeitschrift für Säugetierkunde 39 (2): 109 -115.

Malatesta, A., 1980. Dwarf Deer and Other Late Pleistocene Fauna of the "Simonelli" Cave in Crete. Quaderno Accademia Nazionale dei Lincei, Roma 249: 1-128.

Mayhew, D. F., 1977. The endemic Pleistocene murids of Crete I-II. Proceedings of the Koninklijke Nederlandse Akademie van Wetenschappen, Series B, 80 (3): 182-214.

Patterson, C., 1978. Evolution, pp. 1-197. British Museum (Natural History), London.

Petronio, C., 1990. Les cervidés endémiques des îles méditerranéennes. Quaternaire 1 (3-4): 259-266.

Reumer, J. W. F., 1986. Notes on the Soricidae (Insectivora, Mammalia) from Crete, I. The Pleistocene species Crocidura zimmermanni. Bonner zoologische Beiträge 37 (3): 161-171. 
— Payne, S., 1986. Notes on the Soricidae (In-sectivora, Mammalia) from Crete, II. The shrew remains from Minoan and Classical Kommos. Bonner zoologische Beiträge 37 (3).

Sickenberg, O., 1975. Eine Säugetierfauna des tieferen Biharium aus dem Becken von Megalopolis (Peloponnes, Griechenland). Annales Géologiques des Pays Helléniques 27: 25-73, Athena.

Simonelli, V., 1907. Mammiferi quaternari dell'isola di Candia I. Memmorie, Accademia delle Scienze. Instituto di Bologna Classe di Scienze Fisiche, ser. VI, no. 4: 455-471, Bologna.

- 1908. Mammiferi quaternari dell'isola di Candia II. Memorie, Accademia delle Scienze. Instituto di Bologna Classe di Scienze Fisische ser. VI, 5: 103-111, Bologna.

Sondaar, P. Y., 1971. Palaeozoogeography of the Pleistocene Mammals from the Aegean. In: Strid, A., ed., Evolution in the Aegean. Opera Botanica 30: 60-70.

1977. Insularity and its effect on mammal evolution, In: Hecht, M. N., Goody, P. C. \& Hecht, B. M., eds., Major patterns in vertebrate evolution, pp. 671-707. Plenum Publishing Corporation, New York.

\& Boekschoten, G. J., 1967. Quaternary mammals in the south Aegean island arc with notes on other mammals from the coastal regions of the Mediterranean, I/II. Proceedings of the Koninklijke Nederlandse Akademie van Wetenschappen, Series B, 70 (5): 556-576.

Symeonides, N. \& Sondaar, P. Y., 1975. A new otter from the Pleistocene of Crete. Annales Géologiques des Pays Helléniques 27: 11-24.

Weesie, P. D. M., 1982. A Pleistocene endemic island form within the genus Athene:Athene cretensis n. sp. (Aves, Strigiformes) from Crete. Proceedings of the Koninklijke Nederlandse Akademie van Wetenschappen, Amsterdam, Series B, 85 (3): 323-336.

- 1987. The Quaternary avifauna of Greece, $90 \mathrm{pp}$. Thesis, Utrecht.

Willemsen, G. F., 1980. Comparative study of the functional morphology of some Lutrinae, especially Lutra lutra, Lutrogale perspicillata and the Pleistocene Isolalutra cretensis. Proceedings of the Koninklijke Nederlandse Akademie van Wetenschappen, Amsterdam, Series B, 83 (3): 289-326.

\section{John de Vos} 地中海クレタ島の第四紀シカ類化石相 : その適応放散と絶滅

大量絶㓕の他に，適応放散は生物集団に起こった普通の現象であり，それらは全ての分類群に見いだせる。 適応放散の規模は，時間と生物体の適応性に依存している。地中海のクレ夕島における更新世シ力類の種 またはいくつかのモルフォタイプの存在は, De Vos (1996) によって1回の侵入とその適応放散モデルとし て解釈された。クレタ島のシカは, 約 8,000 年前の人類の到達によって絶减してしまった。 